\title{
Workplace Discourse: Constructing Social Identity of Lecturers Through WhatsApp Group
}

\author{
Yana Shanti Manipuspika ${ }^{*}$, Tantri Refa Indhiarti, Emy Sudarwati
}

Faculty of Cultural Studies, Universitas Brawijaya, Malang, Indonesia

Email address:

yana.manipuspika@gmail.com (Y. S. Manipuspika)

*Corresponding author

\section{To cite this article:}

Yana Shanti Manipuspika, Tantri Refa Indhiarti, Emy Sudarwati. Workplace Discourse: Constructing Social Identity of Lecturers Through WhatsApp Group. International Journal of Language and Linguistics. Vol. 7, No. 1, 2019, pp. 13-22. doi: 10.11648/j.ij11.20190701.13

Received: November 25, 2018; Accepted: January 10, 2019; Published: January 31, 2019

\begin{abstract}
This paper discusses how WhatsApp (WA) group can be used to maintain social and workplace relationship. In the presence of positive mediation of WA, people may have a sense of belonging as WA is a written discourse community. A WhatsApp group of lecturers was used as the source of data. Based on the results of analysis, it was revealed that the lecturers who join this WA group generally attempt to assert their individuality. Yet, they put their efforts to join others by maintaining their sense of status or self-esteem as they are members of the group by doing some imposition. It was also found that rich communication can be realized through WA group. The members' use of greetings and the use of directives are reported. The syntactic and lexical choices made by the lecturers are consciously or subconsciously interpreted by the members of the group. The messages in WA group also revealed that the lecturers in the group show they are able to contribute freely, avoid conflict and create harmonious working relationships via the WA chat forum. The study described here is a case study of a written workplace discourse in an educational institution. Hence no statistical tests have been carried out since it is regarded as exploratory. Further study based on different workplaces and in different contexts needs to be conducted to see how these findings hold for other workplaces.
\end{abstract}

Keywords: Discourse Community, Workplace Discourse, Social Identity, WhatsApp Group

\section{Introduction}

The advancement of communication technology has brought a profound change in today's workplace communication. In recent years, WhatsApp (WA) communication has an unprecedented impact on communication. Through the emergence of mobile phone application, it has become a powerful communication service via the internet to enable people to create a private or group chat. It can be used for relational maintenance in many situations including in social and workplace relationship. In terms of its nature, WA should be positioned somewhere a face-to-face communication and a private message which enables people to engage in real time interaction. It results from its ability for people to transfer files, such as videos, documents, pictures so that social activities are enhanced by providing more opportunities and convenience in communication.
As a still-developing genre of internet-mediated communication, WA has attracted considerable attention from researchers in recent years, with approaches ranging from communication analysis to interpersonal and social pragmatics $[2,13]$. Those studies have tended to focus either on the individual dimension of the interaction studying the exchanges between individuals or on how multi-party conversations emerge. In addition, researchers have studied the social dimensions of online discussion in which multiparty interaction leads to the formation of discourse communities and how to maintain them. The changing communication patterns due to new technologies consequently changes interpersonal relationships. Several findings show that internet-mediated communication is beneficial for interpersonal relationships. A study has indicated that internet communication leads to task orientation, lack of humanity, and affection in messages. However, the detached communication through internet is overcome with the presence of a positive mediation effect, 
such as mood sharing expressing thoughts, being cared for, and mutual understanding, leading to the individual interpersonal relationship [7].

The presence of mediation effect portrays that almost all humans yearn for a sense of belonging by joining a discourse community. It is a group of people who share common values and goals and have a certain way of communicating to achieve the goals. Swales (1990) lists six characteristics of what makes a group of people a discourse community [11]. Firstly, a discourse community has a broadly agreed set of common public goals. Secondly, a discourse community has mechanisms of intercommunication among its members. Thirdly, a discourse community uses its participatory mechanisms primarily to provide information and feedback. Fourthly, a discourse community utilizes and hence possesses one or more genres in the communicative furtherance of its aims. Fifthly, in addition to owning genres, a discourse community has acquired a specific lexis, and sixthly, a discourse community has a threshold level of members with a suitable degree of relevant content and discoursal expertise. In this case, language constructs experience of workplace because, although people live in a physical reality, the concepts, values, and experience are derived from a social linguistic process. Therefore, words should be used to have a profound role in constructing the interaction of the places and spaces. By indicating Swales' six criteria of a discourse community, this research is to bring the sociolinguistic perspective into the workplace discourse research to portray communicational patterns leading to the reflection of social identity of the participants.

People evaluate workplace based on their opinion, attitudes, and ideals through interaction. Accordingly, the language used plays a significant role in shaping the workplace environment [8]. In this workplace, there is a connection between the social and the communicative structure in which the group structure is reflected. Besides, texts produced by the group is a collaborative effort to which the people in the group reading the texts express a strong feeling of their identity that may distinguish this particular group from that in other workplace environments. This correspondence between social identity and workplace discourse, however, may indicate communication problems attributed to lack of understanding of different social communicative styles [10]. It is the essence of sociopragmatic skills that pose a particular challenge for the members in workplace as difficulties with subtle sociopragmatic aspects of communication are perceived negatively. The ability to use language effectively in the workplace is a key in performing successfully in maintaining good collegial relationships with workmates. Thus, it is depicted that the lecturers of Urun Rembug Dosen FIB WhatsApp group brought particular linguistic features of language use when interacting through this forum which then signal their social identity as lecturers and as a member of society as well.

The new practice of WhatsApp (WA) usage has introduced communication intimacy in terms of disclosure and closeness under internet environment. This may lead to the perception that WA is a less formal tool, transmitting an intimate relationship achieved through mutual sharing of information and emotion. On the contrary, there may be the possibility of the risk of sending a response to an unintended person as a result of being overwhelmed by simultaneous conversations in WA communication considered by the users of WA, in this case the lecturers in Faculty of Cultural Studies (FIB) at Universitas Brawijaya (UB). All in all, the members in Urun Rembug Dosen FIB WA Group as a discourse community are always working towards improving the group. This can be achieved by focusing on the same goals, communicating effectively, increasing participation, or helping out those members that are in favor. With all the considerations and by focusing on Swales' 6 criteria of a discourse community, there are two reseach questions formulated: (1) How the lecturers construct their social identity at work place atmosphere through WA chat group? and (2) How does WhatsApp group as a written workplace discourse affect social relationship of the lecturers?

A study on the field using a framework consisting of three dimensions, Iranian users studied in case of variables which construct social identity, consist of full name exposure, benefit from Fake Profiles and level of privacy setting [5]. These variables selected in regard with special characteristics extracted from observation of sample size behaviors during a period of two months, and believed that may reflect a new trait in social identity users present depend on the cultural and domestic concerns. By sending a lot of requests to participate in the online survey, a sample of 308 users agree to include in the online survey. The descriptive statistics felt sufficient for the purpose of study. This study found out that nearly half of Iranian users of facebook did not provide their full name and made some distortions or using abbreviations making it difficult to find for others. Also nearly $40 \%$ of them benefit from fake profile(s) in addition to their main account to surf facebook and share the contents they not prefer to be known for them, such as satire or taboo articles. Also many of them restricted the level of access to their profiles to make the social media as a private social space. The authors concluded that social identity joins with the real identity of the users, and thus they care about their social image in the social media space. Many users believe that despite the freedom from the contents in social media, they will damage for some descent in prestige and image against the others who attend to their profiles, likes and shared articles. Thus they use some policies to joy from social media without being hurt or damaged by the activities in it. They try to make themselves hide and merely invite confident friends to join with, make restrictions to access of others to their shared articles and comments, and benefit from anonymous surfing with fake profiles. The findings of this research despite the simple method used is to attract attentions to the interdependency of identity in real life and in social media space and the effect of real life identity on the image, users tend to present in social media. 


\section{Literature Review}

\subsection{Language and Social Identity}

People define themselves in terms of their social group membership and enact roles as part of their acceptance of the normative expectations of ingroup members. The term social identity refers to a wide variety of social persona covering social status, roles, position, relationship, and institutional and other related communities identifies one may attempt to claim or attempt in the course of social life [9]. This means that social identity addresses every specific detail of a person as a member of a society. This social identity will be the representation of an individual which later will place him/her in certain criteria. She also explains that the relation between language and social identity exists within the process of socialization. Language speakers attempt to build social identities of themselves as well as others through performing certain social acts verbally. A social act is any socially recognized, goal-directed behavior, such as making a request, contracting another person, or interrupting someone [9].

In relation to the language use, social identity is the stimulus and the language behavior is the response. In this case, as language use pervades social life, the elements of social life constitute an intrinsic part of the way language is used. Linguists regard language as an abstract structure that exists independently of specific instances of usage, but any communicative exchange is situated in a social context that constrains the linguistic forms participants use. Therefore, it is understandable that particular linguistic features are selected to signal particular social identities [9]. In other words, a person with a certain identity will use particular linguistic features to signal their social identity. By doing so, they will be easily recognized by others.

This study focuses on the discussion of one of social identities referring to a workplace. This means that the researchers focus on how someone's workplace can reflect a person's social identity.

\subsection{Workplace Discourse}

The term 'workplace' refers to the institution or a place where a person belongs to as a result of his employment. Workplace will attach a person to his responsibility over a certain task to be accomplished and all responsibilities brought by this.

In the setting of a certain workplace, there will be various kinds of talks occurring among its members. The talks might vary, ranging from office tasks to chatty conversation involving members of the same working place. Workplace talk occurs in a wide range of settings from a talk between co-workers to interactions in service encounters or healthcare settings, to international business communication [5]. These varieties of setting may result in various phenomena suggesting whether the talks carried out belong to formal or informal one.

In the workplace, there is institutional talk which is frequently used in the literature to refer to interactions in all kinds of workplace setting. Institutional talk differs from ordinary conversation in a number of ways [6]. Institutional talk is an institutional interaction which is often asymmetrical (although casual conversation is only symmetrical at a certain level of idealization). Institutional roles may be linked to certain discursive rights and obligations, for example in terms of initiating and controlling interactions, asking questions, and so forth. In lay-professional encounters, there is often asymmetry of knowledge about the goals and procedures of the interaction: for the professional the encounter is often routine, whereas for the lay-person it may be new, and he may be unaware of the professional's objectives. In such encounters, access to expert knowledge is often unequal. At the same time as professionals possess expert knowledge which their lay-clients do not have, they are also often reluctant to commit themselves (and thereby their institution) to firm positions, and thereby display epistemological caution [6]. In professional and workplace interactions, participants therefore take on particular institutional roles which are often asymmetrical (e.g., doctorpatient, teacher-student, and employer-employee). However, it cannot simply be assumed that these institutional roles are always relevant to the talk in which speakers are engaged.

A talk happening in a particular workplace will arise participant's goal orientation. This participants' goal orientation is reflected in a number of features of workplace talk, for example in the recurrence of particular types of discursive activity which can be associated with specific workplace practices, such as instruction-giving, decisionmaking, and briefing.

For many workers, perhaps most, the workplace represents the place where they can share thoughts and the same interest. In the workplace, workers can even develop a sort of social life referring to the need of interacting to each other.

\subsection{Discourse Community}

Discourse communities are groups that have goals or purposes, and use communication to achieve these goals [11]. In other words, it is a group of people who share a set of discourses, understood as basic values and assumptions, and ways of communicating about those goals. Each discourse community has its own unwritten rules about what can be said and how it can be said.

The term 'discourse community' was first used by sociolinguist Martin Nystrand in 1982, and further developed by American linguist, John Swales. He presents six defining characteristics of a discourse community, namely: (1) It has a broadly agreed set of common public goals, (2) It has mechanisms of intercommunication among its members, (3) It uses its participatory mechanisms primarily to provide information and feedback, (4) It utilizes and hence possesses one or more genres in the communicative furtherance of its aims, (5) In addition to owning genres, it has acquired some specific lexis (terminology, jargon), (6) It has a threshold level of members with a suitable degree of relevant content and discoursal expertise (not everybody can participate) [10]. 


\subsection{Campus Life as a Workplace Discourse}

Getting things done at work involves a variety of sociolinguistic skills. In campus life, there is an interaction involving lecturers, students, administrative staffs, and policy makers. In the interaction, people involved need to know how to use language in ways which do not only avoid giving offence but also which actively take account of people's need to maintain "face". Members of a certain institution will pay attention to interpersonal relations so they will choose appropriate ways of asking people to do things for them, and who recognize that allowing time for small talk and humor in the workplace can make the difference between a dull, uninspired and uninspiring workforce.

In campus life, lecturers have their own way of socializing; that involves the aspect of politeness and solidarity. Lecturers will not only deal with how to get things done but they also concern on the importance of a small talk at work which may enhance the solidarity among its members. One of the medias that the lecturers use to interact to each other is by using the social media, in which they can share thoughts, ideas, and experiences as well as comments on general issues.

\subsection{Social Media and WhatsApp Application}

The world changes very fast due to the advancement of technology. These days it seems hard to escape from the presence of technology. Most people are engaged with many technological gadgets that they use in their everyday lives. The internet nowadays grows at an incredible speed as well. Many of us depend on it to get us through the day, to do our job, to get around, and to find certain things. Technology is evolving at a very fast rate, and what most people do not even think could be real a few years ago, is now becoming a reality. One of the technological advancements is the application of social media.

Social media can be defined as forms of electronic communication through which users interact among people in which they create, freely share, exchange, and discuss information, ideas, personal messages, and other content about each other and their lives using a multimedia. The platforms such as Facebook, Twitter, MySpace and YouTube are available for everyone; it was traditionally created to connect with individuals from all over the world to include employees, friends and families. Social media has changed the way people around the globe communicate with one another.

WhatsApp is one of the changes in technology that is commonly used on smartphones and computers. Since smartphones became popular, many messaging services were launched and WhatsApp has become very popular among them. The main purpose behind this application is to replace SMS with a cross-platform mobile messenger that works on an internet data plan. If we have unlimited text, it is still beneficial as it is a convenient way to skip international fees that carriers may charge (www.whatsapp.com).

The WhatsApp messenger was purposely created by Brian Acton and Jan Koum (2009) to make communication and the distribution of multimedia messaging more easily and faster. It creates the opportunity to network with other members who share similar or common interest, dreams and goals. With the social media network like WhatsApp, an individual can initiate and build strong business partnership in any part of the world without meeting that individual in person. With WhatsApp messenger, communication through mobile phones has become easier, faster and cheaper.

\section{Research Method}

\subsection{Research Design}

In this study, the research is toward a better understanding of the function of WhatsApp group in constructing social relationship among lecturers as the members of Urun Rembug Dosen FIB WA group and the way they construct their social identity. The chat group has been initially created by some lecturers on behalf of the faculty to interact with one another on a daily basis, and thus the conversation topics are free and covered both professional and social topics.

Therefore, the approach used in this study is a qualitative one in which the inquirer makes knowledge claim based on the multiple meanings of individual experience meanings socially [4]. In other words, the researchers seek to establish the meaning of a phenomenon from the view of the participants and observe participants' behaviors by participating in their activities - in this case, in WA group.

\subsection{Data Source}

Data used in this study were the written conversation of lecturers. The data were gathered from a mobile phone WA group-chat conversation of lecturers in Faculty of Cultural Studies during a one-month period (mid June - July 2017). One month is appropriate time to ensure sufficient data. Considering the ethical issue in this research, the subjects were not contacted, manipulated, or influenced during the data gathering. Additionally, with regards to confidentiality assurance, no information to identify the subjects was released, and the permission of individuals in authority was gained after the data were collected by invoicing writing a letter identifying the extent of time and the potential impact for the study.

\subsection{Data Collection}

The researchers obtained the data through direct contact with a group of persons in their natural state as undisturbed as possible in an observation, as suggested by [3]. In doing so, the researchers had gained access and been accepted by the group of individuals being observed as they are the members of Urun Rembug Dosen FIB WA chat group. In collecting the data, the researchers copied all the conversations produced by the members of the group.

\subsection{Data Analysis}

Data analysis in qualitative approach ...involves reducing 
and organizing the data, synthesizing, searching for significant patterns, and discovering what is important [1]. The researchers were demanded to be able to organize the data which have been collected and compose a report by giving the interpretation. Those processes need a deep comprehension of the topic under study. Thereby, several steps below were taken to analyze the data:

\section{Identifying}

The researchers identified the language used by the lecturers of Urun Rembug Dosen FIB forum by looking at some particular linguistic features brought when interacting via WA group.

\section{Analyzing the data}

The researchers analyzed the data that have been previously identified by referring to the theory of workplace discourse proposed by Koster (2004) and Swales (1990).

3. Interpreting the data

The researchers interpreted the use of language by the lecturers and connected it to the social identity they have as lecturers.

\section{Drawing conclusion}

After interpreting the results of the data analysis, the researchers drew conclusion of the research.

\section{Research Results}

This study focuses on the effort in revealing the social identities referring to a workplace. In this section, the data taken from WA group Urun Rembug Dosen FIB were analyzed in detail to reveal the correlation between a person's written comment on workplace discourse and his/her social identity. Therefore, there must be certain linguistic features to signal particular social linguistic features.

\subsection{Linguistic Features of Written Workplace Discourse}

A person with a certain identity will use particular linguistic features to signal his/her social identity. By doing so, this person will be easily recognized by others. Lecturers of FIB also perform certain linguistic features when they give comments via WA grup of Urun Rembug Dosen FIB.

Table 1. Linguistic Features of Written Workplace Discourse.

\begin{tabular}{|c|c|c|}
\hline Linguistic Features & & Excerpts \\
\hline \multirow[t]{3}{*}{ Greeting in the message } & 1 & $\begin{array}{l}\text { AZ: Assalamu'alaikum...Selamat Idul Fitri bapak ibu...Mohon maaf atas segala kesalahan. Semoga tahun depan kita } \\
\text { dipertemukan kembali dengan bulan Ramadhan }(24 / 6 / 2017 \text { 19.19) } \\
\text { SKK: Selamat Idul Fitri...Mohon maaf lahir dan batin ...Selamat berkumpul dengan keluarga.(24/6/2017 21.08) } \\
\text { SVE: Slamat siang...Selamat Idul Fitri, Bapak Ibu semua...saya mohon maaf atas semua kesalahan saya dan } \\
\text { keluarga...Semoga kita selalu dalam lindunganNya }(25 / 6 / 2017 \text { 13.11) }\end{array}$ \\
\hline & 2 & $\begin{array}{l}\text { IW: Hi it's me peeps } \\
\text { MSH: Perkenalkan Bu Bulan.. } \\
\text { IP: hai mbak Wulan...welcome } \\
\text { SUT: Welcome Mbak Bulan.... (14/6/2017 12.05) }\end{array}$ \\
\hline & 3 & FNS: Assalamu'alaikum, Bapak Ibu. Mohon maaf lahir dan batin apabila ada salah kata dan perbuatan. \\
\hline \multirow[b]{2}{*}{ Using forms of directives } & 4 & JL: Bapak Ibu apa ada yang punya ember bekas cat 25 kilo-an? Nuwun (3/7/2017 15.42) \\
\hline & 5 & $\begin{array}{l}\text { INR: Bapak Ibu... adakah yang tertarik sayur dan buah segar serta botok, pepes, krupuk puli dkk? Masih banyak di } \\
\text { gerai biasanya dekat MAKO sebelah rektorat. (16/6/2017 15.14) }\end{array}$ \\
\hline
\end{tabular}

\section{Greeting in the Message}

One of the norms of human behaviour is that people greet each other when they come into contact and exchange ritualistic words of closure when they part. Greetings and closings perform a valuable social role. This role as offerring formulas to ease the strain created for face by the beginning and end of interactions [4]. In this case, the opening phase is to lubricate the transition from non-interaction to interaction and to ease the awkward moments of the encounter before the main business of the encounters embarked upon. Meanwhile, the closing phase is outward to the resumption of social life outside of the momentary relationship of the encounter. All in all, these greeting and closure in the institution have been carried over into people's discourse behaviour. Nearly all messages begin with a greeting or some acknowledgement of the addressee and have some forms of closure at the end as they personalise the message and by so doing helps it to achieve its objective. Excerpt 1 is indicative of the attittude of the WA users. The excerpt displays that the messages begin with any form of greeting and there is no consistency to the pattern of their opening use. Some messages begin with an address term then greeting. Greeting by using the word selamat is used to indicate a feeling of happiness upon one's big day celebration in this case is welcoming the Eid Al-Fitr of Moslem.

Another example of greeting uses the word welcome and $h i$ can be found in Excerpt 2, which shows greetings addressed to someone who just join the group. The word welcome is used to signal happy feeling upon someone's participation in the group. The use of the words welcomes and $H i$ signals a certain social status that the persons who just join the group belong to a certain community, in this case, the person belongs to the faculty community. By saying $\mathrm{Hi}$ it's me peeps, the writer wants to show her identity, to what group she belongs. Seeing from the degree of formality, saying $\mathrm{Hi}$ and welcome is also meant to minimize the distance between members of the group.

Another greeting is signalled by the word Assalamu'alaikum which is formal, as can be seen in Excerpt 3. Here the writer shows much respect to all members of the group by saying a greeting Assalamu'alaikum. It seems that the speaker is being careful for not making mistake or 
creating uneasiness. The writer of this WA chat intentionally uses this greeting to maintain the degree of formality and to keep being polite.

\section{Using Forms of Directives}

Directives provide a rich data source for examining how the variables of social distance is actualized in people's workplace discourse. It also provides a means for examining people's relational practice and the extent to which the workplace culture is instantiated in people's WA style. Because directives are inherently face-threatening acts, they enable the people to see how WA writers negotiate workplace relationships and make their messages less face-threatening while at the same time getting things done or accomplishing their transactional goals. The directives need to not only make clear what the required action is, but it must also negotiate power and social distance relationships in a way that provides evidence of respect and concern for the feelings of others. Thus it is useful to see what strategies people can do to minimise the face threat of a directive and ensure the addressee's full co-operation.

By showing how WA message is used to convey both transactional and affetive messages in many ways and how readers draw on their own situational knowledge to interpret meaning, this study illustrates how directives are used in WA communication. The term directive used in this study is therefore limited to the utterances where the action to be performed is more or less at cost to the addressee.

Three forms in which directives are realised are the imperatives, the interrogative, and the declarative. Imperatives are the most direct and explicit form of directive by commanding the reader to do as requested and it is not necessarily impolite. It is because maximum efficiency is important which is recognized by both writer and reader. In the findings, interrogatives are dominantly used, as reflected in Excerpt 4.

An interrogative is a form involving the reversal of the subject and verb and using an auxiliary. The interrogative sentence in the above datum appears to function as a directive in the context of the group chat. The interrogative can be considered the least face-threatening form of directive as it leaves the addresses more freedom of action (read the action to explain, or answer, or to produce speech act). In Excerpt 5, the addressser might not explicitly require a response. The directive shown above can be inherently seen as a less face-threatening act. The sentence enables the people to see how WA writers negotiate workplace relationships and make their messages less face-threatening while at the same time getting things done or accomplishing their transactional goals. The goal to have a pre-used bucket, or to simply inform others, is accomplished. The directive need does not only make clear the required action. At the same time, it is succeeded to negotiate the power of the addresser (the writer) and social distance relationships in a way that provides evidence of respect and concern for the feelings of others through the use of address term 'Bapak Ibu' instead of 'Teman-teman'. It is also successful to minimise the face threat of the directive sentence since the sentence is not addressed to certain people. At last, the addresser is sure that she/he has ensured the addressee's full co-operation.

\subsection{Participant's Goal Orientation Reflected Through Workplace Discourse}

A discourse happens in a particular workplace will arise participant's goal orientation. This participants' goal orientation is reflected in a number of features of workplace talk, for example in the recurrence of particular types of discursive activity which can be associated with specific workplace practices, such as giving instruction, giving invitation, requesting, and suggesting or giving advice. The following is the analysis concerning the discourse practice in Urun Rembug Dosen FIB via WA Group.

Table 2. Goal Orientation Reflected through Workplace Discourse.

\begin{tabular}{|c|c|c|}
\hline Goal Orientation & & Excerpts \\
\hline Requesting & 6 & $\begin{array}{l}\text { YH: Selamat pagi Bapak Ibu, Klrg PSIK mohon maaf lahir dan batin } \\
\text { Selamat bekerja kembali. Mohon tetap waspada dg ransomware nggih(3/7/2017 09.57) }\end{array}$ \\
\hline Commanding & 7 & $\begin{array}{l}\text { AN: Bpk ibu yth. Silakan update info terkait pengerjaan venue MTQMN XV 2017. Monggo yang ingin menikmati } \\
\text { sajian MTQ. (25/7/2017 07.50) } \\
\text { SM: Kepada Bapak Ibu Dosen FIB, ada undangan terbuka Lailatul Qiro'ah dalam rangkaian kegiatan MTQMN }\end{array}$ \\
\hline Inviting & 8 & $\begin{array}{l}2017 \text { pada Senin: } 31 \text { Juli } 2017 \text { pk } 19.00 \text { di Masjid Raden Patah (Ruang Utama).Mohon berkenan meneruskan } \\
\text { pesan ini kepada yang lain. Terima kasih. (25/7/2017 15.20) }\end{array}$ \\
\hline
\end{tabular}




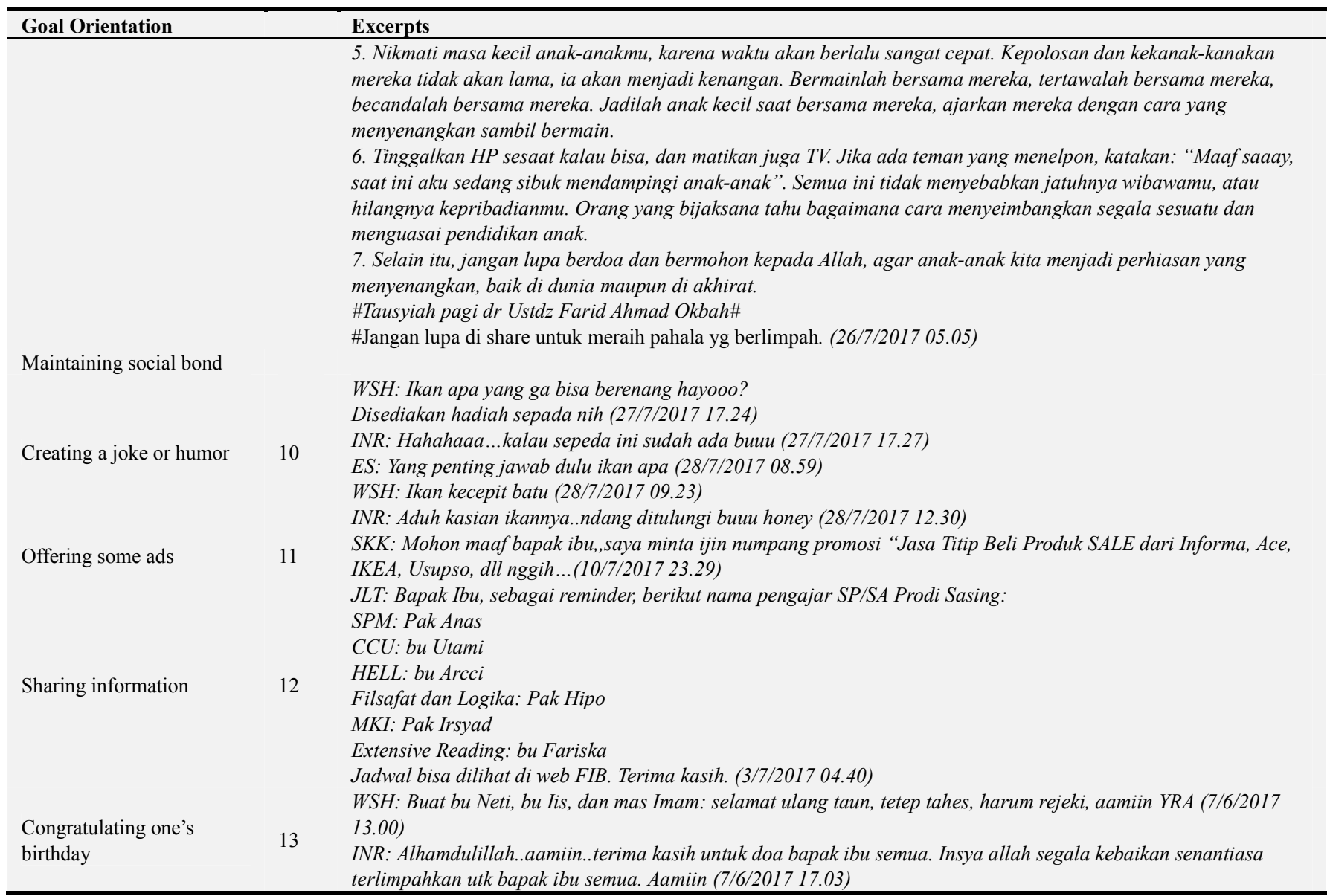

\section{Requesting}

Requesting is one of the motives of a participant when delivering a talk through a workplace discourse. Excerpt 6 from WA chat in Urun Rembug Dosen FIB forum seem to represent this goal. The writer in the above excerpt intends to ask for a request instead of giving a command. By doing so, it seems that she tries to minimize the distance but not asking directly what her goal but rather she mentions the word mohon to show politeness. She tries to get anyone in the community involve in the goal she is heading on. She seems want to make the whole members in this community to be aware of the situation around campus. Politeness can be dispensed so directives do not need to be mitigated and may even be boosted as is the case here, e.g. note the use of mohon. The indirect way in which many message directives are realized seems to reflect an effort to balance the goals of either asking someone to do something and the goal of maintaining social relationship.

The person asking for a request is involved in persuading the other person to act as they would like them to act. One strategy that a person use to perform a request is by using linguistic features which are less face threatening or less of an affront to the hearer by being indirect.

\section{Commanding}

Commands and orders often take the imperative form while more 'polite' attempts may use interrogatives or declaratives. While imperatives are generally considered to be the most forceful kind of directive followed by declaratives and interrogatives, context as much as syntactic form is important in determining directive force. Excerpt 7 seems to represent the idea.

Here the writer seems very clear in delivering his goal that is command by asking everyone to go to a specific goal. He is very direct in delivering his command which might indicate his particular position in that workplace. Therefore, the intention is delivered to the point so that everyone knows what to do. The use of signaling words like silakan, and monggo indicate the goal of minimizing the closeness with the addressee. Status difference seems play its role as the writer is aware on the role of status difference between him and his interlocutors.

Seeing from the use of command in the previous explanation, it is then clear that particular linguistic form chosen is likely to be influenced by such variables as the relative status of the two interlocutors, the social distance between them, which may in turn be a product of their status difference, their gender, the particular context in which the interaction takes place, and the nature and reasonableness of the task.

\section{Inviting}

Another goal of a person being involved in a workplace discourse is giving an invitation to someone. This motive is actually the same as command but it is less demanding as it is made up in the form of invitation. The force of a directive 
reflected in an invitation can be reduced by many linguistic, pragmatic and other means such as modal verbs and particles, hedges, interrogatives and negative and positive politeness strategies. In this case, resourceful writers are able to take advantage of the possibilities the medium of message offers and exploit it in highly creative ways to reduce the illocutionary force of their directives. The message sequence below provides a good example of how these mitigating features are used in WA messages and illustrates the effect that the FTA, status and social distance can have on the way in which the message is written. Excerpt 8 represents this particular goal. The writer of this message performs directive act in the form of invitation. It is not a command as the speaker seems fully aware that there are certain people who might be unable to attend the event. Therefore, the use of signaling word mohon indicates that the invitation is less demanding.

\section{Giving advice / suggestion}

The terms giving advice and the making of suggestions are somewhat problematic, but they have been included as directives as they are an attempt by a person to get another to do something. Excerpt 9 shows suggestion as well as advice, in which the writer's intention of giving an advice and suggestion by pointing out the lesson she got from a noted public figure. In this case, the speaker is aware on what community she is in, so that she is is being considerate in delivering her suggestion in such a way that it will not create an insult but a motivation, instead. The writer is aware that the community she is addressing consists of the knowledgeable persons. In return to what she is doing, a participant in the group gives her appreciation by giving her a token of gratitude in the forms of emoticon and direct appraisal.

\section{Maintaining Social Bond}

The following examples illustrate how status difference is over-ridden when social distance is low. Of more importance than status is the closeness and length of the relationship. In this kind of work relationship where each person knows their own duties and responsibilities they can be very direct about things that are part of what the other person expects to do. However, sometimes in a workplace setting, there are things that each member of the group does to maintain the closeness or the social bond among them by presenting topics out out the reach for example by creating a joke or a humor, sharing experiences, delivering some ads, and presenting an information as well as congratulating others.

\section{a. Creating a joke or humor}

Apart of being serious, in this occasion (Excerpt 10) the writer (WSH) tries to deliver a joke which she considers it might refresh the situation and makes the relationship among group members closer. The speaker tries to attract the other members' attention though this joke. In this situation, the speaker tries to minimize the role of social status among the members which are the lecturers, yet she tries to direct the members to certain direction that they might not realize their actual status as lecturers.

b. Offering some ads
Workplace is identical with tasks to complete. However, in some occasions workplace discourse can also be fulfilled by some activities like offering some ads or offering a product. It is not necessarily improper in its context, but it is merely done as a 'breaking the ice' moment so that the stuffs discussed might not be that serious on task completion only. In excerpt 11, the writer tries to refresh the situation by offering her products. This is done as a means of maintaining the social relations among members of this group. The writer intends to catch member's attention by responding to her offer. By doing so, the members will be actively involved in responding the products offered. Indirectly, it is a way to maintain the social bond among them.

\section{c. Sharing information}

Sharing information can be one of the ways to maintain the social bond among group members. This activity shows one's care and attention toward others as the information he/she gives might be helpful for the members. Excerpt 12 shows the writer's concern on the group members' schedule so she shares information as a reminder. This way is considered important as this can be one of the ways to signal effort in maintaining the social bond among group members.

\section{d. Congratulating one's birthday}

Congratulating on one's birthday is another way of maintaining the social bond among group members. It is shown in excerpt 13. From birthday wishes, the relationship among members will be closer and the members will be accustomed to congratulating on each other's birthdays as they realize that this can be one of the ways of showing sympathy to build and strengthen the social bond among them.

\section{Discussion}

To define social identity in the workplace setting, the lecturers who join Urun Rembug Dosen FIB WhatsApp Group generally attempt to assert their individuality. They also put their efforts to join others by maintaining their sense of status or self-esteem as they are members of the group by doing some imposition. In this study, people -the professionals in academic setting -construct personal and group identities through continuous interaction with others through WA group. In the workplace context, it includes the way the lecturers construct themselves as good leaders and or good colleagues and peers.

In this present study, colleagues are showing their willingness to share their experiences, show their empathy, express their gratitude and also discuss academic matters with the members of the group. Their personal identities are shown when expressing individual responses, while the group identities are shown when they agree on communal belief or simply express their joy for the faculty's success.

In this study, the directives were also examined to see if task complexity had some bearing on whether or not they were foregrounded or backgrounded. For this purpose they were categorized into one of these groups depending on the nature of the request: (1) simple questions requiring either no 
or very little explanation, e.g. apa ada bapak Ibu yang butuh sayuran segar? And (2) requests requiring follow-up action after an update or a briefing, such as Bapak Ibu ada yang punya no telp KTU? which is produced in response to the update for name tag for lecturers.

The written discourse directives in this WA message did differ in their surface form. This suggests that directives WA message produced by the lecturers tend to be less direct. They are more to be made to avoid imposing other members of the group. The explanation for this may be that the immediacy of WA and the addresser's knowledge of many of the addressees tends to lead to greater use of less direct forms.

Similar aspects are also proven to be true in this research. Since WA is a real time conversation, direct responses toward an information or input are unavoidable, but those are not an exchange of the spoken discourse.

Writers of WA in the group of Urun Rembug Dosen FIB attempt to engage in a various strategies to mitigate the force of their directives, the great majority of which are softened in some way. Their status and to a lesser extent their gender and degree of closeness are enacted in the language of WA message directives, mostly are just as they are in the forms of casual spoken, while others are in the forms of written language. Members of the group are of equal status. Nonetheless, some members are considered of higher status than other members. Thus, they write unbare, as an attempt to mitigate directives and not to impose other members. They use more softeners in their mitigated directives, like the use of address terms, hedges, and fillers. However, this may in part be explained by the fact that most of their messages were long and written like to close colleagues. Many were also replies to previous messages. Hence politeness in this group is very relative and context-dependent. Thus, while WA directive messages play role in the construction of power and distance relations in the workplace, the messages in the data of this study also show that most writers, regardless of their status, are concerned with constructing affective interpersonal relationships. Thus, in many of the messages there is a good balancing of the transactional and affective functions.

Aside than those explained above, this study of written workplace discourse has shown that rich communication can be realized through WA group. The syntactic and lexical choices made by the lecturers are interpreted consciously or subconsciously by the members of the group. By drawing on their own knowledge of the context, issues and people involved, the discourse in workplace is well enacted. It can be seen too, how the workplace discourse can provide an enabling context since they enable person-to-person interaction and engage a whole group in advancing their field of practice, communities of practice are ideal medium for leveraging tacit knowledge

The messages in WA group also reveal that the lecturers as the members of the group are trying play their role in developing the positive and caring working relationships which they realize the key of successful shared knowledge creation and closer relationship among members. They also had a very important interactive function. Both positive and negative politeness strategies have been used in this work of relationship building. The positive politeness strategies used, such as acknowledging the difficulties of others and showing appreciation of what they have done, giving reasons for requests, using humour and friendly informal greetings, helped to build a friendly, co-operative professional working relationship. By using these politeness strategies, members of the WA group involved were able to show closeness, solidarity and rapport. By making use of negative politeness strategies such as, using respectful greetings and indirect forms of request many of which were softened, the group members involved showed respect for the face needs of the other person and minimised the imposition posed by the requests they had to make in order to get their professional work done and establish new working systems.

The lecturers' WA messages indicate that the members felt able to contribute freely, conflict was avoided and harmonious working relationships established in a period of considerable stress and anxiety. They demonstrate the importance of affective interpersonal facework for facilitating shared knowledge and creation of stronger relationship. Since this affective interpersonal facework exists, Urun Rembug Dosen FIB WA messages are particularly useful in supporting the processes of combining existing explicit knowledge, and ensuring ongoing cooperation.

\section{Conclusion}

Based on the findings and analysis, it was revealed that the lecturers who join the Urun Rembug Dosen FIB Group generally attempt to assert their individuality. Yet, they put their efforts to join others by maintaining their sense of status or self-esteem as they are members of the group by doing some imposition. In this study, it is revealed that rich communication can be realized through WA group. The members' use of greetings and the use of directives are reported. The syntactic and lexical choices made by the lecturers are consciously or subconsciously interpreted by the members of the group. The messages in WA group also revealed that the lecturers as the members of the group play their roles in developing positive and caring working relationships. In addition, they also had a very important interactive function. In this relationship building at workplace, both positive and negative politeness strategies have been used.

To conclude, the lecturers in Urun Rembug Dosen FIB show they are able to contribute freely, avoid conflict and create harmonious working relationships via the WA chat forum.

The study described here is a case study of a written workplace discourse in an educational organisation. Hence no statistical tests have been carried out since it is regarded as exploratory. Further study based on different workplaces and in different contexts needs to be conducted to see how 
these findings hold for other workplaces. Amongst other things the aim of the study described here is to construct a broad general picture of institutional and individual WA usage. While it has shown that WA is used with and alongside other communication media to work through issues, a fruitful area of enquiry would be to examine at a micro level how the different communication media including WA are used in the resolution of an issue to better understand the contribution that each makes in combination with others.

\section{References}

[1] Ary, D., Jacobs, L. C. and Sorensen, C. K. (2010). Introduction to Research in Education: Sixth Edition. Belmont: Wadsworth.

[2] Church, K. and de Oliveira, R. (2013). What's up with WhatsApp? Comparing Mobile Instant Messaging Behaviors with Traditional SMS. Retrived 10 July 2015 from http://www.ic.unicamp.br/ oliveira/doc/MHCI2013_Whatsup-with-whatsapp.pdf.

[3] Creswell, J. W. (2003). Research Design: Qualitative, Quantitative, and Mixed Methods Approaches. SAGE Publication.

[4] Eckert, P. and McConnell-Ginet, S. (2003). Language and Gender. Cambridge: Cambridge University Press.
[5] Heivadi, T. and Khajeheian, D. (2013). Construction of Social Identity in Social Media: An investigation of Iranian Users' Appearance in Facebook. Interdisciplinary Journal of Contemporary Research in Business, Vol. 4, No. 12.

[6] Koester, A. (2004). Investigating Workplace Discourse. New York: Routledge.

[7] Lin, C., Sun, Y., Lee, Y., and Wu, S. (2007). How Instant Messaging Affects the Satisfaction of Virtual Interpersonal Behaviour of Taiwan Junior High School Students. Adolescence, 42 (166), 417-430.

[8] Markus, T. And Cameron, D. (2002). The Words between the Spaces -Buildings and Language. London: Routledge.

[9] Ochs, E. (1993). Constructing Social Identity: Language Socialization Perspective. Lawrence Elbraum Associate.

[10] Rose, K. R. (2005). On the effects of instruction in second language pragmatics. System, 33(3), 385-399.

[11] Swales, J. M. (1990). Genre Analysis: English in Academic and Research Settings. Cambridge: Cambridge University Press.

[12] WhatsApp Frequently Asked Questions. Retrieved on June 10, 2015 from www.whatsapp.com.

[13] Yeboah, J. and Ewur, G. D. (2014). The Impact of Whatsapp Messenger Usage on Students Performance in Tertiary Institutions in Ghana. Retrieved 10 July 2015 from iiste.org/Journals/index.php/JEP/article/download/11241/1155 5 . 